OPEN ACCESS

Edited by:

Edvaldo Antonio Ribeiro Rosa, Pontifícia Universidade Católica do

Paraná, Brazil

Reviewed by:

Rafael Guerra Lund,

Universidade Federal de Pelotas,

Brazil

Osmar Nascimento Silva, Universidade Católica Dom Bosco,

Brazil

*Correspondence: André L. S. Santos andre@micro.ufri.br

Specialty section:

This article was submitted to Antimicrobials, Resistance and

Chemotherapy,

a section of the journal

Frontiers in Microbiology

Received: 12 May 2017

Accepted: 23 June 2017

Published: 11 July 2017

Citation:

Gandra RM, Mc Carron P, Fernandes MF, Ramos LS, Mello TP, Aor AC, Branquinha MH, McCann M,

Devereux M and Santos ALS (2017)

Antifungal Potential of Copper(II),

Manganese(II) and Silver(I)

1,10-Phenanthroline Chelates Against Multidrug-Resistant Fungal Species

Forming the Candida haemulonii Complex: Impact on the Planktonic and Biofilm Lifestyles.

Front. Microbiol. 8:1257.

doi: 10.3389/fmicb.2017.01257

\section{Antifungal Potential of Copper(II),} Manganese(II) and Silver(I) 1,10-Phenanthroline Chelates Against Multidrug-Resistant Fungal Species Forming the Candida haemulonii Complex: Impact on the Planktonic and Biofilm Lifestyles

\author{
Rafael M. Gandra 1,2, 3 , Pauraic Mc Carron ${ }^{3,4}$, Mariana F. Fernandes ${ }^{1}$, Livia S. Ramos ${ }^{1}$, \\ Thaís P. Mello ${ }^{1}$, Ana Carolina Aor ${ }^{1}$, Marta H. Branquinha ${ }^{1}$, Malachy McCann ${ }^{4}$, \\ Michael Devereux ${ }^{3}$ and André L. S. Santos ${ }^{1,2 *}$ \\ ${ }^{1}$ Laboratório de Investigação de Peptidases, Departamento de Microbiologia Geral, Instituto de Microbiologia Paulo de \\ Góes, Universidade Federal do Rio de Janeiro, Rio de Janeiro, Brazil, ${ }^{2}$ Programa de Pós-Graduação em Bioquímica, Instituto \\ de Química, Universidade Federal do Rio de Janeiro, Rio de Janeiro, Brazil, ${ }^{3}$ The Inorganic Pharmaceutical and Biomimetic \\ Research Centre, Focas Research Institute, Dublin Institute of Technology, Dublin, Ireland, ${ }^{4}$ Chemistry Department, \\ Maynooth University, National University of Ireland, Maynooth, Ireland
}

Candida haemulonii, Candida haemulonii var. vulnera and Candida duobushaemulonii, which form the $C$. haemulonii complex, are emerging etiologic agents of fungal infections known to be resistant to the most commonly used antifungals. The well-established anti-Candida potential of metal complexes containing 1,10-phenanthroline (phen) ligands encouraged us to evaluate different copper(II), manganese(II), and silver(I) phen chelates for their ability to inhibit planktonic growth and biofilm of $C$. haemulonii species complex. Two novel coordination complexes, $\left\{\left[\mathrm{Cu}(3,6,9 \text {-tdda)(phen) })_{2}\right] \cdot 3 \mathrm{H}_{2} \mathrm{O} \text {. EtOH }\right\}_{\mathrm{n}}$ and $\left[\mathrm{Ag}_{2}(3,6,9\right.$-tdda)(phen) 4 ]. EtOH (3,6,9-tddaH $2=3,6,9$-trioxaundecanedioic acid), were synthesized in a similar fashion to the other, previously documented, sixteen copper(II), manganese(II), and silver(I) chelates employed herein. Three isolates of each C. haemulonii species complex were used and the effect of the metal chelates on viability was determined utilizing the CLSI standard protocol and on biofilm-growing cells using the XTT assay. Cytotoxicity of the chelates was evaluated by the MTT assay, employing lung epithelial cells. The majority of the metal chelates were capable of interfering with the viability of planktonic-growing cells of all the fungal isolates. The silver complexes were the most effective drugs (overall geometric mean of the minimum inhibitory concentration (GM-MIC) ranged from 0.26 to $2.16 \mu \mathrm{M}$ ), followed by the manganese (overall GM-MIC ranged from 0.87 to $10.71 \mu \mathrm{M}$ ) and copper (overall GM-MIC ranged from 3.37 to $>72 \mu \mathrm{M})$ chelates. The manganese chelates $\left(\mathrm{CC}_{50}\right.$ values ranged from 234.51 to $>512 \mu \mathrm{M})$ were the least toxic to the mammalian cells, followed by the silver $\left(\mathrm{CC}_{50}\right.$ values ranged from 2.07 to $13.63 \mu \mathrm{M})$ and copper $\left(\mathrm{CC}_{50}\right.$ values ranged from 0.53 
to $3.86 \mu \mathrm{M})$ compounds. When tested against mature biofilms, the chelates were less active, with MICs ranging from 2- to 33-fold higher levels when compared to the planktonic MIC counterparts. Importantly, manganese(II), copper(II), and silver(I) phen chelates are relatively cheap and easy to synthesize and they offer significant antifungal chemotherapeutic potential for the treatment of highly resistant pathogens.

Keywords: Candida haemulonii complex, metal-based drugs, 1,10-phenanthroline, antifungal activity, antivirulence, biofilm

\section{INTRODUCTION}

The global incidences of invasive candidiasis has increased considerably in recent decades, being the fourth and sixth leading cause of nosocomial blood infections in the United States of America and Europe, respectively (Caggiano et al., 2015). New advances in medicine have improved the survival rates of innumerous patients, but also resulted in an augment in the number of immunocompromised individuals, who are extremely susceptible to systemic mycoses (Richardson and Lass-Flörl, 2008; Sanguinetti et al., 2015). Infections caused by non-albicans Candida species, such as Candida parapsilosis, Candida glabrata, Candida tropicalis, and Candida krusei, are becoming increasingly more common in hospital settings (Abu-Elteen and Hamad, 2012; Ramos et al., 2015). This new scenario constitutes a clinical challenge, since such nonalbicans Candida species are more resistant to the different classes of antifungal drugs that are currently available (AbuElteen and Hamad, 2012; Ramos et al., 2015). This trend is also being observed for fungal infections caused by other uncommon species such as those belonging to the Candida haemulonii complex (C. haemulonii, Candida duobushaemulonii and Candida haemulonii var. vulnera). The risk or predisposing factors associated with fungemia caused by $C$. haemulonii complex include mechanic ventilation, serious conditions such as cancer and immunodeficiency and the use of central venous catheters (Almeida et al., 2012; Cendejas-Bueno et al., 2012; Muro et al., 2012). Given the epidemiological profile of the C. haemulonii complex and the fact that it is resistant to such a broad spectrum of the state-of-the-art antifungals (e.g., amphotericin B, flucytosine, fluconazole, itraconazole, voriconazole, micafungin, and caspofungin) (Giusiano et al., 2005; Khan et al., 2007; Kim et al., 2009; Ruan et al., 2010), it is imperative that the scientific community examine alternative therapeutic paths for it treatment. Aggravating this scenario, recently, our research group described the ability of C. haemulonii species complex to form biofilm on inert substrate (Ramos et al., 2017). From a medical viewpoint, the microbial biofilm architecture is a complex and robust structure, which is extremely resistant to different classes of drugs (e.g., antifungals and disinfectants), host immune attack (e.g., antibodies, antimicrobial peptides, and complement proteins) and several hostile environmental stressors (e.g., dehydration and radiation; Nett, 2014; Ramage et al., 2014; Mello et al., 2017). Anti-biofilm strategies able to prevent and/or eradicate fungal biofilms in medical devices are urgently required (Ramage et al., 2014; Ramos et al., 2017).
The anti-Candida activity of transition metal chelates containing 1,10-phenanthroline (phen) ligands is already wellestablished, and it is known that copper(II)-, manganese(II)-, and silver(I)-phen chelates are potent growth inhibitors of C. albicans, C. glabrata, C. tropicalis, and C. krusei (Geraghty et al., 2000; McCann et al., 2000, 2012; Coyle et al., 2003). These compounds affected mitochondrial function, reduced cytochrome $b$ and $c$ synthesis, induced respiratory uncoupling and increased cell wall permeability in the fungal cells (McCann et al., 2004; Creaven et al., 2007). Given the proven anti-Candida profile of phenbased drugs, we decided to examine the anti-C. haemulonii species complex therapeutic potential of a series of copper(II), manganese(II), and silver(I) phen chelates on both planktonic growth and biofilm of nine Brazilian clinical isolates of the C. haemulonii complex. The hypothesis of our study is based on the premise that clinical isolates belonging to the C. haemulonii complex often exhibit resistance to different classes of antifungal agents commonly used in medical practice and, therefore, there is an urgent need to find new active compounds against these emerging fungal species.

\section{MATERIALS AND METHODS}

\section{Chemistry}

Chemicals were purchased from commercial sources and used as received without further purification. Infrared (IR) spectra were recorded in the region $4,000-370 \mathrm{~cm}^{-1}$ on a Perkin Elmer System 2000 FT spectrometer and using anhydrous potassium bromide to form solid $\mathrm{KBr}$ discs. Elemental analysis (CHN) was carried out for all the complexes using a FLASH EA 1112 Series Elemental Analyser with Eager 300 operating software. Room temperature, solid state magnetic susceptibility measurements for the $\mathrm{Cu}(\mathrm{II})$ compounds, $\left[\mathrm{Cu}(3,6,9\right.$-tdda) $] \cdot \mathrm{H}_{2} \mathrm{O}$ and $\left\{\left[\mathrm{Cu}(3,6,9 \text {-tdda })(\text { phen })_{2}\right] \cdot 3 \mathrm{H}_{2} \mathrm{O} \cdot \mathrm{EtOH}\right\}_{\mathrm{n}} \quad$ (7), were made using a Johnson Matthey Magnetic Susceptibility Balance.

The following metal chelates were prepared using previously published methods: $\left[\mathrm{Cu}(\mathrm{ph})(\mathrm{phen})\left(\mathrm{H}_{2} \mathrm{O}\right)_{2}\right]$ (1) $\left(\mathrm{phH}_{2}=\right.$ phthalic acid) (Kellett et al., 2012); $\quad\left[\mathrm{Cu}(\mathrm{ph})(\mathrm{phen})_{2}\right] .3 \mathrm{H}_{2} \mathrm{O} .2 \mathrm{EtOH} \quad$ (2) (Kellett et al., 2011); [Cu(isoph)(phen $\left.)_{2}\right] \cdot 6 \mathrm{H}_{2} \mathrm{O} . \mathrm{EtOH}$ (isophH $\mathrm{C}_{2}=$ isophthalic acid) (Kellett et al., 2011); $\left[\left\{\mathrm{Cu}(\text { phen })_{2}\right\}_{2}\right.$ (terph)](terph). $13.5 \mathrm{H}_{2} \mathrm{O} .2 \mathrm{EtOH}$ $\left(\right.$ terph $\mathrm{H}_{2}=$ terephthalic acid) (Kellett et al., 2011); $\left.\quad\left[\mathrm{Cu}_{2} \text { (oda)(phen }\right)_{4}\right]\left(\mathrm{ClO}_{4}\right)_{2} \cdot 2.76 \mathrm{H}_{2} \mathrm{O}$.EtOH $\left(\right.$ odaH $_{2}=$ octanedioic acid) (Devereux et al., 1999); $\left.[\mathrm{Cu} \text { (phendione })_{3}\right]\left(\mathrm{ClO}_{4}\right)_{2} \cdot 4 \mathrm{H}_{2} \mathrm{O} \quad$ (6) (phendione = 
1,10-phenanthroline-5,6-dione) (McCann et al., 2004); $\left[\mathrm{Mn}(\mathrm{ph})(\mathrm{phen})\left(\mathrm{H}_{2} \mathrm{O}\right)_{2}\right] \quad$ (8) (Devereux et al., 2000); $\left[\mathrm{Mn}(\mathrm{ph})(\mathrm{phen})_{2}\left(\mathrm{H}_{2} \mathrm{O}\right)\right] .4 \mathrm{H}_{2} \mathrm{O}$ (9) (Devereux et al., 1999); $\left.\left[\mathrm{Mn}_{2} \text { (isoph) }\right)_{2}(\mathrm{phen})_{3}\right] \cdot 4 \mathrm{H}_{2} \mathrm{O}$ (10) (Devereux et al., 2000); $\left\{\left[\mathrm{Mn}(\text { phen })_{2}\left(\mathrm{H}_{2} \mathrm{O}\right)_{2}\right]\right\}_{2}$ (isoph) $)_{2}$ (phen). $12 \mathrm{H}_{2} \mathrm{O}$ (11) (Devereux et al., 2000); [Mn(tereph)(phen $\left.)_{2}\right] .5 \mathrm{H}_{2} \mathrm{O}$ (12) (Leon, 2000); $\left.\left[\mathrm{Mn}_{2} \text { (oda) (phen }\right)_{4}\left(\mathrm{H}_{2} \mathrm{O}\right)_{2}\right]\left[\mathrm{Mn}_{2}\right.$ (oda) $\left.(\text { phen })_{4}(\text { oda })_{2}\right] .4 \mathrm{H}_{2} \mathrm{O}(\mathbf{1 3})$ (Casey et al., 1994); $\left\{\left[\mathrm{Mn}(3,6,9 \text {-tdda })(\text { phen })_{2}\right] \cdot 3 \mathrm{H}_{2} \mathrm{O} \cdot \mathrm{EtOH}\right\}_{\mathrm{n}}$ (14) (3,6,9-tddaH $\mathrm{H}_{2}=3,6,9$-trioxaundecanedioic acid) (McCann et al., 1997); $\left[\mathrm{Ag}(\text { phendione })_{2} \mathrm{ClO}_{4}\right.$ (15) (McCann et al., 2004); $\left[\mathrm{Ag}(\text { phen })_{2}\right] \mathrm{ClO}_{4}$ (17) (McCann et al., 2004) and $\left[\mathrm{Ag}_{2} \text { (phen) }\right)_{3}$ (udda) $] .3 \mathrm{H}_{2} \mathrm{O}$ (18) $\left(\mathrm{uddaH}_{2}=\right.$ undecanedioic acid) (Thornton et al., 2016). The novel complexes, $\left\{\left[\mathrm{Cu}(3,6,9-\mathrm{tdda})(\mathrm{phen})_{2}\right] \cdot 3 \mathrm{H}_{2} \mathrm{O} \cdot \mathrm{EtOH}\right\}_{\mathrm{n}}$ (7) and $\left[\mathrm{Ag}_{2}(3,6,9-\right.$ tdda)(phen $\left.)_{4}\right]$.EtOH (16), were synthesized using the two-step procedures outlined below. The preparation of all silver compounds was conducted in the absence of light and the products were stored in the dark.

$\left\{\left[\mathbf{C u}(3,6,9-\text { tdda })(\text { phen })_{2}\right] \cdot 3 \mathrm{H}_{2} \text { O.EtOH }\right\}_{n} \quad$ (7). Step (i): Copper(II) acetate hydrate $(1.50 \mathrm{~g} ; 7.51 \mathrm{mmol})$ was dissolved in ethanol $(50 \mathrm{~mL})$ and the solution was added to an ethanolic solution $(25 \mathrm{~mL})$ of 3,6,9-trioxaundecanedioic acid $(3,6,9$ $\mathrm{tddaH}_{2}$ ) (2.84 g; $8.95 \mathrm{mmol}$ ). The light-green suspension was refluxed for $1 \mathrm{~h}$, and after cooling to room temperature the light-green solid, $[\mathrm{Cu}(3,6,9$-tdda $)] \cdot \mathrm{H}_{2} \mathrm{O}$, was filtered off, washed with cold ethanol and air dried. Yield: $1.88 \mathrm{~g}(82.97 \%)$. \% Calculated: C: $31.84, \mathrm{H}: 4.68$. \% Found: C: $32.20, \mathrm{H}: 4.60$. IR $(\mathrm{KBr}) \nu_{\max }: 3280,2930,1585,1430,1330,1250,1130,1090$, 1055, 965, 920, 840, 720, $475 \mathrm{~cm}^{-1} \cdot \mu_{\text {eff: }} 1.93$ B.M. Solubility: soluble in $\mathrm{H}_{2} \mathrm{O}, \mathrm{MeOH}, \mathrm{EtOH}$ and insoluble in $\mathrm{CHCl}_{3}$, ethyl acetate and acetone. Step (ii): $\left[\mathrm{Cu}(3,6,9\right.$-tdda) $] \cdot \mathrm{H}_{2} \mathrm{O}(1.00 \mathrm{~g} ; 3.31$ $\mathrm{mmol})$ and phen $(2.39 \mathrm{~g} ; 13.26 \mathrm{mmol})$ were dissolved together in ethanol $(50 \mathrm{~mL})$ and the resulting dark-green mixture was refluxed for $2 \mathrm{~h}$. The suspension was cooled and the green solid, $\left\{\left[\mathrm{Cu}(3,6,9 \text {-tdda })(\text { phen })_{2}\right] 3 \mathrm{H}_{2} \mathrm{O} \cdot \mathrm{EtOH}\right\}_{\mathrm{n}}(7)$, was filtered off, washed with cold ethanol and air dried. Yield: $1.63 \mathrm{~g}(66.09 \%)$. \% Calculated: C: 54.87, H: 5.42, N: 7.53. \% Found: C: 54.65, H: 5.63, N: 7.39. IR (KBr) $\nu_{\max }: 3982,3415,3041,2901,1989,1752$, $1618,1587,1513,1421,1320,1252,1221,1121,1090,1077,1011$, $934,893,847,770,720,704,643,619,603,573,555,507,426$ $\mathrm{cm}^{-1}$. $\mu_{\text {eff: }} 1.92$ B.M. Solubility: soluble in $\mathrm{H}_{2} \mathrm{O}, \mathrm{MeOH}, \mathrm{EtOH}$ and insoluble in ethyl acetate and acetone.

[ $\left.\mathbf{A g}_{2}(\mathbf{3 , 6}, \mathbf{9}-\mathbf{t d d a})(\mathbf{p h e n})_{4}\right]$.EtOH (16). Step (i): Silver(I) acetate $(3.00 \mathrm{~g} ; 17.97 \mathrm{mmol})$ was dissolved in ethanol $(30 \mathrm{~mL})$ and the solution was added to an ethanolic solution $(25 \mathrm{~mL})$ of 3,6,9-trioxaundecanedioic acid (3,6,9-tddaH $)_{2}(2.84 \mathrm{~g} ; 8.95$ $\mathrm{mmol}$ ) and the orange-brown suspension refluxed for $3 \mathrm{~h}$. After cooling to room temperature, the light orange-brown powder, $\left[\mathrm{Ag}_{2}(3,6,9\right.$-tdda $] \cdot 2 \mathrm{H}_{2} \mathrm{O}$, was filtered off, washed with cold ethanol and then air dried. Yield: $3.79 \mathrm{~g}$ (44.69\%). \% Calculated: C: 20.36, H: 2.56. \% Found: C: 20.34, H: 2.51. IR $(\mathrm{KBr}) \nu_{\max }: 3425,2896,1614,1406,1116 \mathrm{~cm}^{-1} .{ }^{1} \mathrm{H}$ NMR: $\left(\mathrm{D}_{2} \mathrm{O}\right)$ $\delta=3.81(\mathrm{~s}, 4 \mathrm{H}), 3.56(\mathrm{~s}, 8 \mathrm{H})$. Solubility: soluble in hot $\mathrm{H}_{2} \mathrm{O}$ and hot DMSO. Step (ii): $\left[\mathrm{Ag}_{2}(3,6,9\right.$-tdda $] .2 \mathrm{H}_{2} \mathrm{O}(0.50 \mathrm{~g} ; 1.06$ $\mathrm{mmol})$ and phen $(0.827 \mathrm{~g} ; 4.589 \mathrm{mmol})$ were dissolved together in ethanol $(40 \mathrm{~mL})$ and the mixture refluxed overnight. After cooling to room temperature the mixture was placed in an ice bath. Green $\left[\operatorname{Ag}_{2}(3,6,9-\right.$ tdda $\left.)(\text { phen })_{4}\right]$.EtOH (16) precipitated and was filtered off, washed with cold ethanol and air dried. Yield: 0.83 g (65.10\%). \% Calculated: C: 57.92, H: 4.19, N: 9.32 . \% Found: C: 57.75, H: 5.16, N: 9.02. IR (KBr) $\nu_{\max }$ : 3380, 3046, 2905, 1978, 1804, 1618, 1585, 1509, 1421, 1322, 1263, 1215, 1121, 1077, 1018, 932, 890, 838, 726, 621, 465, $413 \mathrm{~cm}^{-1} .{ }^{1} \mathrm{H}$ NMR (500 MHz, DMSO-d6, $313 \mathrm{~K}, \mathrm{TMS}) \delta=9.12(8 \mathrm{H}, \mathrm{s}), 8.63(8 \mathrm{H}, \mathrm{d})$, $8.08(8 \mathrm{H}, \mathrm{s}), 7.91(8 \mathrm{H}, \mathrm{dd}), 3.74(4 \mathrm{H}, \mathrm{s}), 3.57(8 \mathrm{H}, \mathrm{dd}) .{ }^{13} \mathrm{C} \mathrm{NMR}$ (125 MHz, DMSO-d6, $313 \mathrm{~K}, \mathrm{TMS}) \delta=173.41,151.28,143.57$, $138.03,129.24,127.37,124.74,71.44,70.42,69.74$. Solubility: soluble in $\mathrm{H}_{2} \mathrm{O}, \mathrm{MeOH}, \mathrm{EtOH}$ and insoluble in ethyl acetate and acetone.

\section{Epithelial Cell Lineage and Microorganisms' Growth Conditions}

Three clinical isolates of each species that form the C. haemulonii complex were used in this study: C. haemulonii (LIPCh4 from finger nail, LIPCh7 from toe nail, and LIPCh12 from blood), C. duobushaemulonii (LIPCh1 from finger nail, LIPCh6 from toe nail, and LIPCh8 from blood) and C. haemulonii var. vulnera (LIPCh5 from toe nail, LIPCh 9 from urine, and LIPCh11 from blood) (Ramos et al., 2015). The fungal isolates were identified by the automatized system VITEK $^{\circledR} 2$ and then characterized by ITS1-5.8S-ITS2 gene sequencing (Ramos et al., 2015). Fungal cells were cultured in Sabouraud-dextrose medium under constant agitation $(130 \mathrm{rpm})$ for $48 \mathrm{~h}$ at $37^{\circ} \mathrm{C}$. Human lung adenocarcinoma A549 cells were maintained in culture flasks containing DMEM medium supplemented with $10 \%$ fetal bovine serum at $37^{\circ} \mathrm{C}$ in an atmosphere of $5 \% \mathrm{CO}_{2}$.

\section{Effects of Test Compounds on Planktonic Fungal Growth}

Susceptibility profile assays were performed in accordance with the broth microdilution protocol described in the document M27-A3 published by the Clinical and Laboratory Standards Institutes (CLSI, 2008). Samples of the test chelates were dissolved in DMSO $(500 \mu \mathrm{L})$ and then serially diluted in a 96-well plate containing RPMI 1640 (Sigma-Aldrich, USA) to give the concentration range of $0.0625-32 \mathrm{mg} / \mathrm{L}$. Aqueous solutions of the metal-free phen ligand and the simple metal salts, $\mathrm{MnCl}_{2}, \mathrm{CuCl}_{2}$, and $\mathrm{AgNO}_{3}$, were also screened over the same concentration range. Caspofungin (Sigma-Aldrich) was used as a classical antifungal agent able to block the growth of all clinical isolates of C. haemulonii species as previously reported by our research group (Ramos et al., 2015). Water dilutions containing DMSO concentrations corresponding to those used to prepare the drug solutions were assessed in parallel. Untreated and compound-treated fungal cells were incubated at $37^{\circ} \mathrm{C}$ for $48 \mathrm{~h}$ and the minimal inhibitory concentration (MIC) was established as the lowest compound concentration where no cellular growth could be detected by visual inspection in accordance to the CLSI recommendation. The geometric mean of the MIC values (GM-MIC) of each compound against all the fungal isolates was calculated using the software, Microsoft Office Excel 2013. 


\section{Mammalian Cell Toxicity Assay and Determination of Selectivity Indexes}

The cytotoxicity was evaluated using the MTT [3-(4,5dimethylthiazol-2-yl)-2,5-diphenyl tetrazolium bromide] (Sigma-Aldrich) assay (Mosmann, 1983). A549 cells $\left(10^{4}\right)$ were seeded into tissue culture plates (TPP, Switzerland) and cultured for $24 \mathrm{~h}$ at $37^{\circ} \mathrm{C}$ in a $5 \% \mathrm{CO}_{2}$ in order to obtain cellular confluence. The wells were then washed twice with DMEM to remove non-adherent cells and the test compounds were added (in concentrations ranging from 0.0313 to 512 $\mu \mathrm{g} / \mathrm{mL}$ ) to plates containing DMEM, followed by a $48 \mathrm{~h}$ incubation period under the same conditions mentioned above. The cellular viability was evaluated by adding MTT to each well and incubating the plates in the dark for $3 \mathrm{~h}$, allowing the viable cells containing active mitochondrial dehydrogenase enzymes to metabolize MTT-tetrazolium salt into purple formazan. The formazan crystals were then dissolved in DMSO $(100 \mu \mathrm{L})$ and the absorbance $(450 \mathrm{~nm})$ measured using a Thermomax Molecular Device microplate reader. The concentration capable of reducing cellular viability by $50 \%$ $\left(\mathrm{CC}_{50}\right)$ was calculated, and the selectivity index (SI) determined using the following equation: $\mathrm{A} 549 \mathrm{CC}_{50} /$ C. haemulonii complex GM-MIC.

\section{Effects of Test Compounds on Biofilm-Growing Cells}

The effect of the compounds on biofilm-growing cells was determined using the previously described microtiter-based technique (Ramage et al., 2001). The fungi $\left(10^{6}\right.$ yeast cells) were incubated for $48 \mathrm{~h}$ at $37^{\circ} \mathrm{C}$ in 96 -well polystyrene microtiter plates (Corning ${ }^{\circledR}$, Corning Incorporated, USA) containing Sabouraud-dextrose broth to accommodate biofilm formation. Following biofilm formation, the culture medium was aspirated and non-adherent cells removed by thoroughly washing the wells three times with sterile PBS $(0.15 \mathrm{M} \mathrm{NaCl}, 0.01 \mathrm{M}$ phosphate buffer, $\mathrm{pH}$ 7.2). Afterwards, the compounds, at the same concentrations used in the planktonic assays, were added to the wells, and the plates were incubated for further $48 \mathrm{~h}$ at $37^{\circ} \mathrm{C}$. The metabolic activity was then evaluated using a colorimetric assay that measures the metabolic reduction of 2,3-bis (2-methoxy-4-nitro-5-sulfophenyl)-5-[(phenylamino) carbonyl]-2H-tetrazolium hydroxide (XTT; Sigma-Aldrich) to a water-soluble, brown formazan product (Peeters et al., 2008). The biofilm MIC (bMIC) for each compound was established as the minimal concentration capable of inhibiting 50\% of metabolic activity when compared to compound-free wells (Ziccardi et al., 2015).

\section{Statistics}

All the experiments were performed in triplicate and in three independent experimental sets. Statistical differences were analyzed by one-way ANOVA and Student's $t$-test, using GraphPad Prism version 5.0 software. In all analyses, $P<0.05$ were considered statistically significant.

\section{RESULTS}

\section{Chelate Synthesis}

With the exceptions of $\left\{\left[\mathrm{Cu}(3,6,9-\text { tdda })(\text { phen })_{2}\right] 3 \mathrm{H}_{2} \mathrm{O} . \mathrm{EtOH}\right\}_{\mathrm{n}}$ (7) and $\left[\mathrm{Ag}_{2}(3,6,9-\right.$ tdda $\left.)(\text { phen })_{4}\right]$.EtOH (16), all of the other copper(II), manganese(II) and silver(I) chelates were prepared and characterized as previously described in the material and methods section. The formulation of chelate 7 was established using elemental analysis, IR spectroscopy and magnetic susceptibility measurements. Chelate $\mathbf{1 6}$ was characterized and formulated based on satisfactory elemental analyses and its IR and ${ }^{1} \mathrm{H}$-NMR spectra. The chemical structures of chelates 1-18 are presented in Figure 1 (in cases where exact solid state structures have not been established using X-ray crystallography tentative structures have been assigned).

\section{Effects of Test Compounds on Planktonic Fungal Growth and Their Toxicity Toward Mammalian Cells}

The capacities of the metal chelates, 1-18, to inhibit the viability of the nine clinical isolates belonging to the C. haemulonii complex are summarized in Table 1. The manganese(II) and silver(I) chelates significantly inhibited the viability of all the fungal isolates. With the exceptions of $\mathbf{1}, \mathbf{2}$, and $\mathbf{4}$, the copper(II) complexes also demonstrated moderate to good antifungal activity. When the isolates where incubated in the presence of the simple salts $\mathrm{CuCl}_{2}$ and $\mathrm{MnCl}_{2}$, no appreciable effects against the fungal cells were observed. In contrast, the simple silver salt, $\mathrm{AgNO}_{3}$, and the metal-free phen and phendione ligands appreciably deterred fungal growth, although not as much as most of the manganese(II) and silver(I) chelates. Aqueous solutions of DMSO, when used at the concentrations used to make up solutions of the metal chelates, were inactive against all the fungal isolates (data not shown).

From an analysis of the GM-MIC values (Table 1) calculated for each copper(II) chelate across all of the nine isolates of C. haemulonii complex, $\left\{\left[\mathrm{Cu}(3,6,9 \text {-tdda })(\text { phen })_{2}\right] 3 \mathrm{H}_{2} \mathrm{O} \cdot \mathrm{EtOH}\right\}_{\mathrm{n}}$ (7) showed the best anti-Candida activity $(\mathrm{GM}-\mathrm{MIC}=3.37 \mu \mathrm{M})$. $\left.\left[\mathrm{Mn}_{2} \text { (oda)(phen }\right)_{4}\left(\mathrm{H}_{2} \mathrm{O}\right)_{2}\right]\left[\mathrm{Mn}_{2}(\right.$ oda $\left.)(\text { phen })_{4}(\text { oda })_{2}\right] \cdot 4 \mathrm{H}_{2} \mathrm{O}(\mathbf{1 3})$ was the most active of the manganese(II) compounds (GMMIC $=0.87 \mu \mathrm{M})$, and this was superseded by the silver(I) compounds, $\left[\mathrm{Ag}_{2} \text { (phen) }\right)_{3}$ (udda) $] \cdot 3 \mathrm{H}_{2} \mathrm{O}(\mathbf{1 8})$ and $\left[\operatorname{Ag}_{2}(3,6,9\right.$ tdda)(phen $\left.)_{4}\right]$.EtOH (16) (GM-MIC $=0.26$ and $0.83 \mu \mathrm{M}$, respectively). Indeed, all of the silver(I) chelates were more active than the simple silver(I) salt, $\mathrm{AgNO}_{3}(3.87 \mu \mathrm{M})$. In general, metal-free phen was $\sim 2$-fold more active than phendione.

The calculated GM-MIC values against each of the fungal species showed some degree of variation. For instance, the GM-MIC values of all the copper(II) compounds (excluding the ones with a GM-MIC value of $32 \mathrm{mg} / \mathrm{L}$ or higher) were lower against $C$. duobushaemulonii species when compared to the C. haemulonii. The same applies when comparing C. duobushaemulonii and C. haemulonii var. vulnera, except for the chelate 6. Contrarily, the silver(I) compounds demonstrated an opposite trend, with C. duobushaemulonii having the higher GM-MIC values for all of the chelates when compared to both of the other Candida species. 


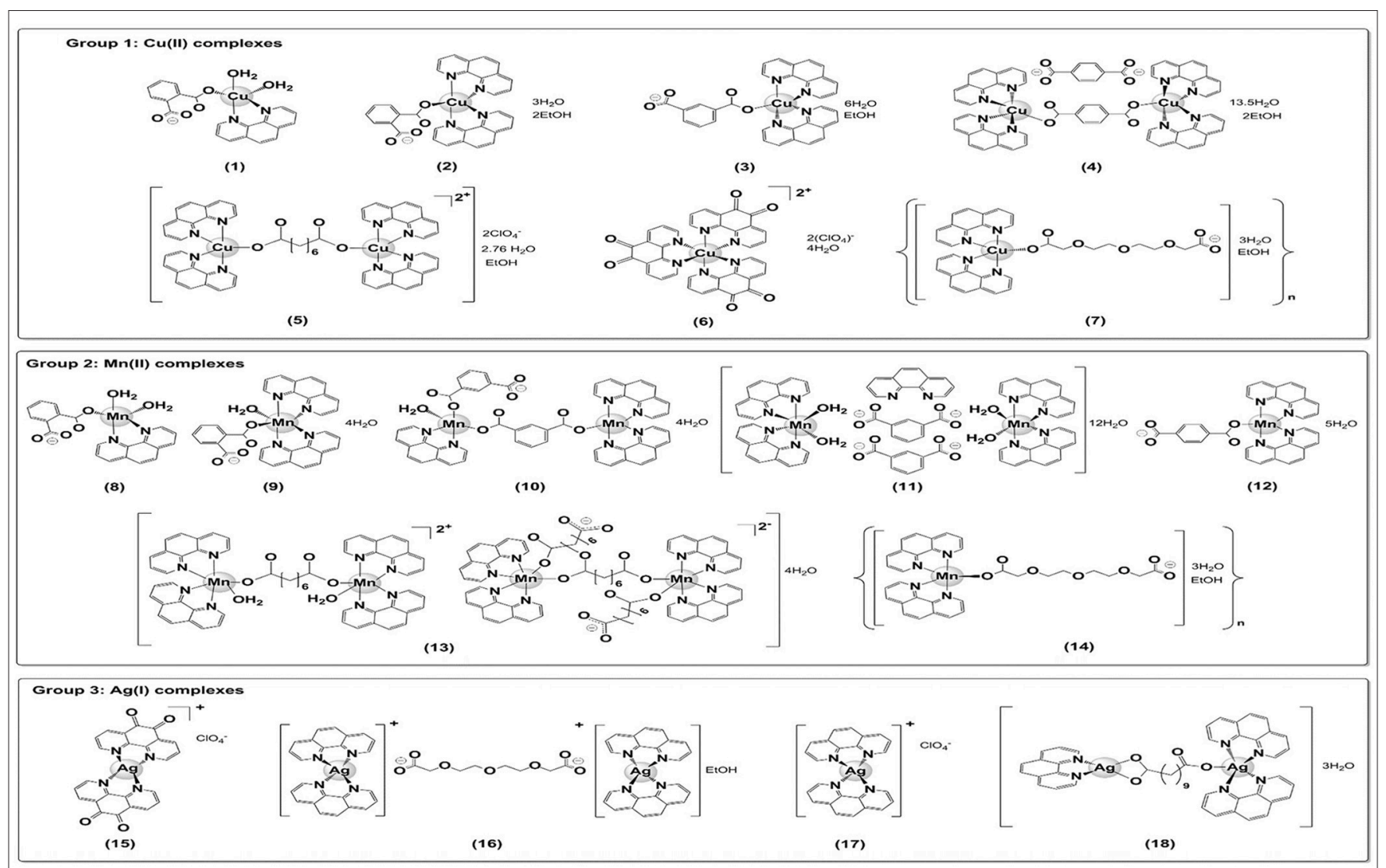

FIGURE 1 | Structures of the copper(II) (1-7), manganese(II) (8-14), and silver(I) (15-18) chelates.

The cytotoxicity of chelates $\mathbf{1 - 1 8}$, the simple metal salts and the metal-free phen and phendione ligands, was assessed using the MTT assay with the lung epithelial cell lineage, A549 (Table 2). The manganese(II)-based complexes were extremely well tolerated by the A549 cells and, consequently, they exhibited the highest SI values (mean SI range $>236.40-48.19$ ) and with $\left[\mathrm{Mn}_{2}\right.$ (oda) $\left.(\text { phen })_{4}\left(\mathrm{H}_{2} \mathrm{O}\right)_{2}\right]\left[\mathrm{Mn}_{2}\right.$ (oda) $\left.(\text { phen })_{4}(\text { oda })_{2}\right] .4 \mathrm{H}_{2} \mathrm{O}(\mathbf{1 3})$ featuring most prominently. Of the remaining test compounds, only water-soluble $\left[\mathrm{Ag}_{2} \text { (phen) }\right)_{3}$ (udda) $] \cdot 3 \mathrm{H}_{2} \mathrm{O}$ (18) and $\mathrm{AgNO}_{3}$ returned relatively high SI values (mean SI $=56.11$ and 27.43, respectively).

\section{Effects of Test Compounds on Biofilm-Growing Fungal Cells}

In this set of experiments, phen, phendione, $\mathrm{AgNO}_{3}$, and the metal-based chelates with overall GM-MIC values of $10 \mu \mathrm{M}$ or less were selected in order to examine their capacity to disrupt fungal viability after biofilm formation on a polystyrene surface. The results (Table 3) revealed that the metal-based compounds were capable of interfering with the biofilm viability in a manner that was to some degree dependent upon the fungal isolate forming the C. haemulonii complex. Overall, the copper(II) chelate 7 , the manganese(II) compounds 11, 13, and 14 and the silver(I) compound $\mathbf{1 6}$ were the most active, presenting bMIC values below $10 \mu \mathrm{M}$. The remaining test complexes had bMIC values ranging from 12.04 to $28.42 \mu \mathrm{M}$. Metal-free phendione and $\mathrm{AgNO}_{3}$ were the least effective agents. Curiously, against several of the test compounds the C. haemulonii isolate, LIPCh4, returned bMIC values exceeding the maximum concentration tested $(512 \mathrm{mg} / \mathrm{L})$.

\section{DISCUSSION}

Invasive opportunistic mycoses are associated with high morbidity and mortality rates, representing serious health challenges and creating a significant burden for both patients and health care systems due to the elevated treatment costs (Caggiano et al., 2015). The reduced number of available effective antifungal drugs and the increasing emergence of resistance profiles have indubitably limited the treatment options of such infections (Abu-Elteen and Hamad, 2012; Almeida et al., 2012; Muro et al., 2012; Ramos et al., 2015; Sanguinetti et al., 2015). The severe difficulties encountered in the treatment of infections caused by the $C$. haemulonii complex obviates the need to explore alternative therapeutic approaches.

The antimicrobial capabilities of metals have been harnessed for centuries, with historical applications in water and food preservation, agriculture and medicine (Lemire et al., 2013). 


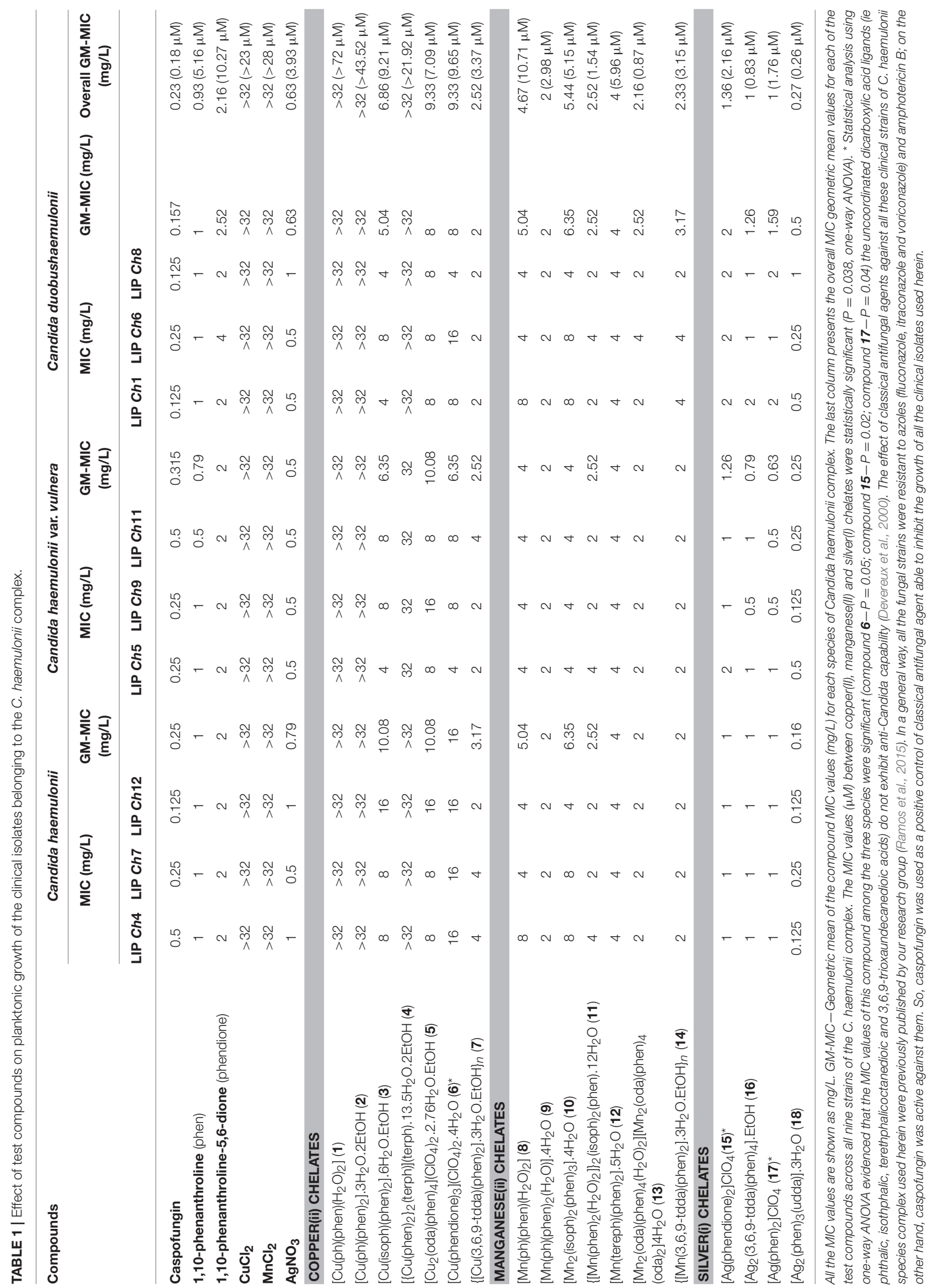


TABLE 2 | Cytotoxicity and selectivity index values of the test compounds.

\begin{tabular}{|c|c|c|c|c|c|}
\hline Compounds & A549 $\left(\mathrm{CC}_{50}\right)$ & C. haemulonii (SI)* & $\begin{array}{c}\text { C. haemulonii } \\
\text { var. vulnera (SI) }\end{array}$ & C. duobushaemulonii (SI) & Overall mean (SI) \\
\hline 1,10-phenanthroline (phen) & 4.30 & 4.30 & 5.42 & 4.30 & 4.67 \\
\hline $\mathrm{CuCl}_{2}$ & 123.68 & $>3.87$ & $>3.87$ & $>3.87$ & $>3.87$ \\
\hline $\mathrm{MnCl}_{2}$ & 133.76 & $>4.18$ & $>4.18$ & $>4.18$ & $>4.18$ \\
\hline$\left[\mathrm{Cu}(\mathrm{ph})(\mathrm{phen})\left(\mathrm{H}_{2} \mathrm{O}\right)_{2}\right](\mathbf{1})$ & 0.53 & $<0.02$ & $<0.02$ & $<0.02$ & $<0.02$ \\
\hline$\left[\mathrm{Cu}(\mathrm{ph})(\mathrm{phen})_{2}\right] \cdot 3 \mathrm{H}_{2} \mathrm{O} \cdot 2 \mathrm{EtOH}(\mathbf{2})$ & 1.93 & $<0.06$ & $<0.06$ & $<0.06$ & $<0.06$ \\
\hline$\left[\mathrm{Cu}(\text { isoph)(phen) })_{2}\right] \cdot 6 \mathrm{H}_{2} \mathrm{O} \cdot \mathrm{EtOH}(\mathbf{3})$ & 0.89 & 0.09 & 0.14 & 0.18 & 0.14 \\
\hline$\left[\left\{\mathrm{Cu}(\text { phen })_{2}\right\}_{2}\right.$ (terph)](terph). $13.5 \mathrm{H}_{2} \mathrm{O} .2 \mathrm{EtOH}(\mathbf{4})$ & 3.86 & $<0.12$ & 0.12 & $<0.12$ & ND \\
\hline$\left[\mathrm{Cu}_{2}\right.$ (oda) $\left.(\text { phen })_{4}\right]\left(\mathrm{ClO}_{4}\right)_{2} \cdot 2 \cdot 76 \mathrm{H}_{2} \mathrm{O} . \mathrm{EtOH}(\mathbf{5})$ & 0.98 & 0.10 & 0.10 & 0.12 & 0.11 \\
\hline$\left[\mathrm{Mn}(\mathrm{ph})(\mathrm{phen})_{2}\left(\mathrm{H}_{2} \mathrm{O}\right)\right] \cdot 4 \mathrm{H}_{2} \mathrm{O}(\mathbf{9})$ & 259.34 & 129.67 & 129.67 & 129.67 & 129.67 \\
\hline$\left[\mathrm{Mn}_{2} \text { (isoph) }\right)_{2}$ (phen) $\left.)_{3}\right] \cdot 4 \mathrm{H}_{2} \mathrm{O}(\mathbf{1 0})$ & 255.87 & 40.30 & 63.97 & 40.30 & 48.19 \\
\hline$\left\{\left[\mathrm{Mn}(\text { phen })_{2}\left(\mathrm{H}_{2} \mathrm{O}\right)_{2}\right]\right\}_{2}(\text { isoph })_{2}$ (phen). $12 \mathrm{H}_{2} \mathrm{O}$ (11) & 251.76 & 99.91 & 99.91 & 99.91 & 99.91 \\
\hline$\left[\mathrm{Mn}(\text { tereph)(phen) })_{2}\right] .5 \mathrm{H}_{2} \mathrm{O}(\mathbf{1 2})$ & 251.94 & 62.99 & 62.99 & 62.99 & 62.99 \\
\hline$\left[\mathrm{Mn}_{2}\right.$ (oda) $\left.\left.(\text { phen })_{4}\left(\mathrm{H}_{2} \mathrm{O}\right)_{2}\right]\left[\mathrm{Mn}_{2} \text { (oda)(phen }\right)_{4}(\text { oda })_{2}\right] 4 \mathrm{H}_{2} \mathrm{O}$ (13) & $>512$ & $>256$ & $>256$ & $>203.19$ & $>236.40$ \\
\hline$\left\{\left[\mathrm{Mn}(3,6,9-\mathrm{tdda})(\text { phen })_{2}\right] \cdot 3 \mathrm{H}_{2} \mathrm{O} \cdot \mathrm{EtOH}\right\}_{n}(\mathbf{1 4})$ & 261.67 & 130.84 & 130.84 & 82.42 & 114.70 \\
\hline \multicolumn{6}{|l|}{ SILVER(I) CHELATES } \\
\hline$\left[\mathrm{Ag}(\text { phendione })_{2}\right] \mathrm{ClO}_{4}(\mathbf{1 5})$ & 3.76 & 3.76 & 2.98 & 1.88 & 2.87 \\
\hline$\left[\mathrm{Ag}_{2}(3,6,9\right.$-tdda)(phen) 4$] \cdot \mathrm{EtOH}$ (16) & 2.21 & 2.21 & 2.78 & 1.75 & 2.25 \\
\hline$\left[\mathrm{Ag}(\text { phen) })_{2}\right] \mathrm{ClO}_{4}(\mathbf{1 7})$ & 2.07 & 2.07 & 3.29 & 1.30 & 2.22 \\
\hline
\end{tabular}

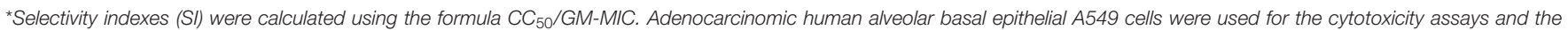
$C^{C} C_{50}$ values are expressed as $\mathrm{mg} / \mathrm{L}$. GM is the geometric mean of the SI values of the compounds against each species of the Candida haemulonii complex.

Inorganic medicinal chemistry, an interdisciplinary research field, is advancing our knowledge of metal toxicity and facilitating the design of metal-containing compounds as effective and targeted antimicrobials, offering a realistic alternative to organic antibiotics (Lemire et al., 2013). We have previously demonstrated that $\mathrm{Cu}(\mathrm{II}), \mathrm{Mn}(\mathrm{II})$, and $\mathrm{Ag}(\mathrm{I})$ chelates containing phen-type ligands exhibit antifungal activity against clinical isolates of C. albicans (Devereux et al., 2000; Geraghty et al., 2000; Coyle et al., 2003; McCann et al., 2004; Creaven et al., 2009). Therefore, we were prompted to assess the antifungal chemotherapeutic potential of this class of metal chelate against the highly resistant $C$. haemulonii species complex. To this end, we tested 16 known chelates (1-6, 8-15, 17, and 18) and 2 new ones (7 and 16), containing either neutral phen or phendione ligands and coordinated or uncoordinated dicarboxylate or perchlorate anions (Figure 1). The complexes, along with the "metal-free" phen and phendione and simple metal salts, were assessed for their ability to inhibit the growth of nine clinical strains of the three species that make up the C. haemulonii complex against both planktonic and biofilm lifestyles. Potent antifungal activity was observed for a number of the test compounds, with the order of planktonic growth inhibition being; chelate $18>16>13>17>11>15>9>14>7>10>12>5>3>6>8$. When the chelates are classified according to the nature of the central metal ion, the silver(I) compounds (15-18) have the best overall growth inhibitory effect, followed by those of manganese(II) (8-14).

While the simple metal salts, $\mathrm{CuCl}_{2}$ and $\mathrm{MnCl}_{2}$, were not able to effectively reduce the fungal cell proliferation, the silver(I) salt exhibited good inhibitory capability. It should be noted that $\mathrm{AgNO}_{3}$ is a well-established source of $\mathrm{Ag}^{+}$ ions, which are well known to have potent antifungal activity (Lemire et al., 2013). Thus, it is fair to assume that the type of metal ion present in the compounds may directly impact their antifungal capability (Devereux et al., 2000; McCann et al., 2004). In contrast, the uncoordinated dicarboxylic acid ligands (e.g., phthalic, isothphalic, terethphalicoctanedioic, and 3,6,9-trioxaundecanedioic acids) are known to not exhibit antiCandida capability, and our results indicate that these ligands also have no effect on the proliferation of the fungal isolates employed in the current study (data not shown) (Devereux et al., 2000). The metal-free (uncoordinated) phen and phendione also had a potent inhibitory effect on the C. haemulonii species complex, 


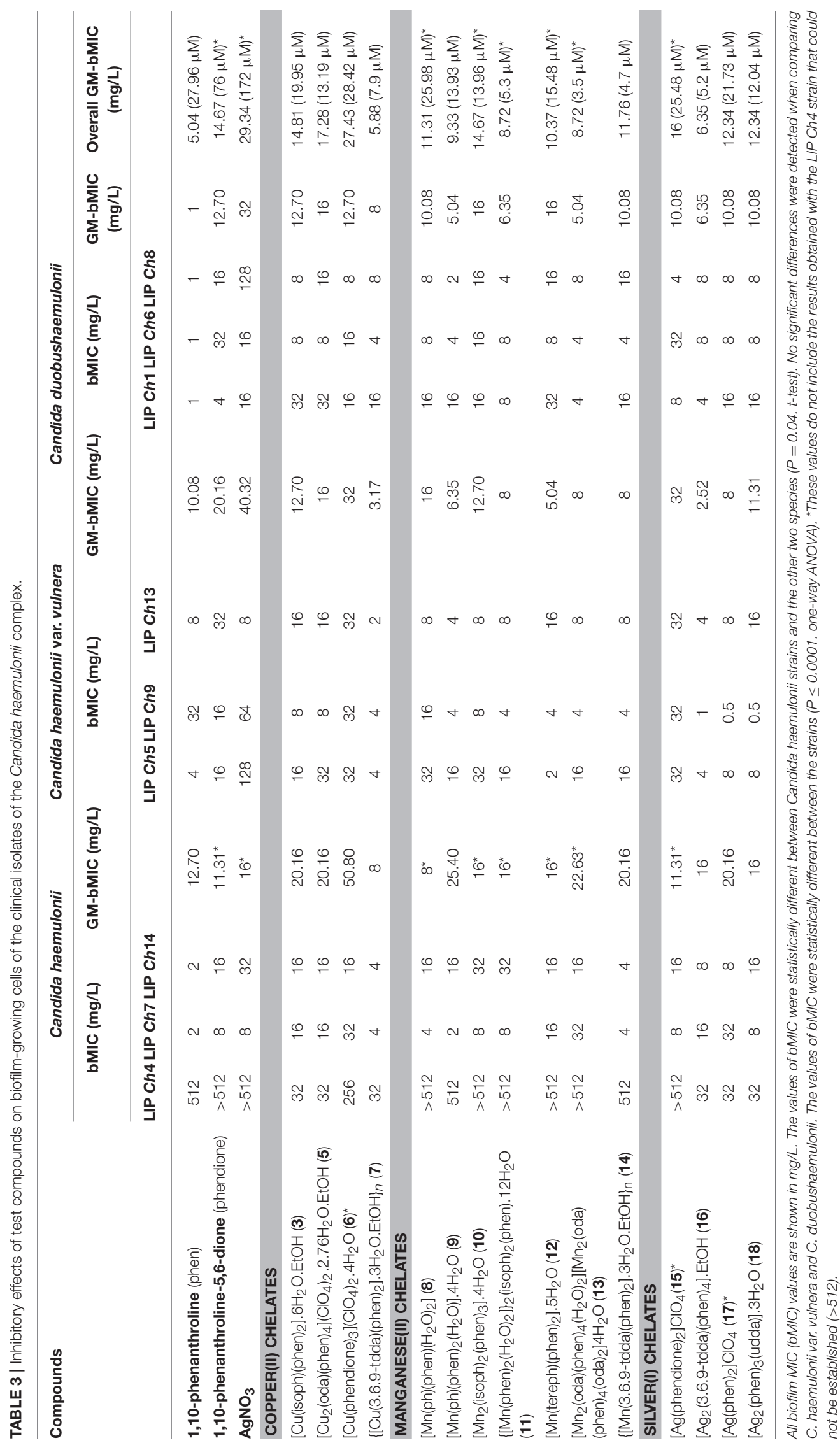


which is in agreement with results obtained from other studies reporting the activity of phen against Candida species such as C. tropicalis, C. krusei and C. glabrata (Geraghty et al., 2000; McCann et al., 2000, 2004, 2012; Coyle et al., 2003). It should be noted that, although metal-free phen and phendione and the $\mathrm{Ag}^{+}$ions (from $\mathrm{AgNO}_{3}$ ) exhibited antifungal activities, the silver(I) chelates (15-18) were able to induce a more pronounced inhibitory antifungal effect based on their overall GM-MIC ( $\mu \mathrm{M}$ values). The same observation applies to the copper(II), 7, and the manganese(II), 9, 10, 11, 13, and 14, chelates, which were more active in inhibiting cellular proliferation than both the corresponding simple metal salt and the "metal-free" phen and phendione ligands, indicating that the chelates are much superior antimicrobial agents. Previous studies into the mode of action of these chelates revealed their potential to disrupt mitochondrial activity and respiration processes, restriction of cell growth by interfering with protein synthesis, cleavage of proteins, DNA interaction/cleavage and epigenetic influences (Devereux et al., 2000; Metcalfe and Thomas, 2003; McCann et al., 2012; Kharissova et al., 2014). These mechanisms of action of the metal chelates differ from those of the azole and polyene drug classes commonly used to treat fungal infections, and they offer the prospect of developing inorganic drugs capable of overcoming the resistance traits that make the treatment of $C$. haemulonii species complex infection so difficult.

An ability to form biofilms is an acknowledged virulence factor of microorganisms, which protects them from the host's immune system and also from the action of antifungal drugs (Mello et al., 2017). Administered drugs experience reduced access to the pathogen as a result of the presence of a biofilm matrix composed of polysaccharides, carbohydrates, proteins and DNA. Besides that, the presence of a biofilm on an implanted medical device may become a reservoir of pathogenic cells that are released to the bloodstream, resulting in dissemination to internal sites and organs (Bujdáková, 2016; Ramos et al., 2017). Candida strains with an inherent ability to establish a biofilm are associated with a higher mortality rate when compared to strains incapable of biofilm formation (Peeters et al., 2008; GarciaVidal et al., 2013; Kawai et al., 2015; Rajendran et al., 2016). The C. haemulonii complex has a considerable biofilm-forming capacity (Bujdáková, 2016; Ramos et al., 2017) and, curiously, the presence of a central venous catheter was mentioned in all of the fungemia case reports regarding these species between 2002 and 2010 (Khan et al., 2007; Almeida et al., 2012; CendejasBueno et al., 2012; Muro et al., 2012). One documented case also describes an outbreak in neonatal patients who were receiving total parenteral nutrition (Kim et al., 2009).

Metal-free phen and phendione, $\mathrm{AgNO}_{3}$ and the chelates 3 and 5-18, which all had shown good in vitro activity against planktonic growth of the three fungal species forming the C. haemulonii complex, were also assessed for their capacity to inhibit the growth of cells in a mature biofilm. The most active were the manganese(II) chelates $13(3.5 \mu \mathrm{M}), \mathbf{1 4}(4.7 \mu \mathrm{M})$ and the silver(I) complex $16(5.2 \mu \mathrm{M})$. Two more compounds were also very effective against the biofilm, the manganese(II) complex 11 and the copper(II) complex 7. A clear reduction in the antifungal capacity of the test compounds was clearly evident on going from planktonic to biofilm cells. The most pronounced decrease in activity was detected for $\left[\mathrm{Ag}_{2} \text { (phen) }\right)_{3}$ (udda) $] .3 \mathrm{H}_{2} \mathrm{O}$ (18) (46.3-fold), followed by $\mathrm{AgNO}_{3}$ (43.8-fold), 17 (12.3-fold), 15 (11.8-fold) and complex 16 (6.3-fold). It is interesting that chelate 18, which was the most active against planktonic cell growth, showed the highest reduction in activity. A degree of variation in compound tolerance amongst the fungal constituent strains of the biofilm is noticeable, with C. haemulonii LIPCh4 being the most defiant. The data obtained in the current study demonstrates that although the test compounds were less active against a biofilm, some had impressively low overall GM-bMIC values, such as chelates $13(3.5 \mu \mathrm{M}), \mathbf{1 4}(4.7 \mu \mathrm{M}), \mathbf{1 6}(5.2 \mu \mathrm{M})$, and $\mathbf{1 1}(5.3 \mu \mathrm{M})$.

In a global scale, there is an urgent demand for the discovery of new therapies with effective, safe and cheap drugs to be used as alternative treatment against (multi)drug-resistant pathogens. In this line of thinking, copper(II), manganese(II) and silver(I) chelates containing phen and phendione ligands are relatively cheap and easy to prepare and they clearly have significant antifungal chemotherapeutic potential against the highly resistant C. haemulonii complex.

\section{CONCLUSIONS}

In summary, the results from the present study indicate that copper(II), manganese(II) and silver(I) chelates containing phen and phendione ligands are capable of inhibiting planktonic and biofilm growth of the three fungal species that comprise the C. haemulonii complex, and which are known to be highly resistant to the most commonly used antifungals. In particular, a number of the manganese(II) and silver(I) complexes were very effective at preventing cellular proliferation and the manganese(II) complexes demonstrated relatively low cytotoxicity toward the mammalian cell line, A549, indicating very favorable selectivity for the $C$. haemulonii species complex.

\section{AUTHOR CONTRIBUTIONS}

RG, MB, and AS conceived and designed the study. RG, PM, MF, LR, TM, and AA performed the experiments. All the authors analyzed the data. MM, MD, MB, and AS contributed reagents, materials, and/or analysis tools. RG, MM, MD, MB, and AS wrote and revised the paper. All the authors contributed to the research and approved the final version of the manuscript. All the authors agree to be accountable for all aspects of the work.

\section{FUNDING}

This study was supported by Fundação de Amparo à Pesquisa no Estado do Rio de Janeiro (FAPERJ), Conselho Nacional de Desenvolvimento Científico e Tecnológico ( $\mathrm{CNPq}$ ), Coordenação de Aperfeiçoamento de Pessoal de Nível Superior (CAPES), Research Brazil Ireland (RBI) and Science Foundation Ireland (SFI). 


\section{REFERENCES}

Abu-Elteen, K. H., and Hamad, M. A. (2012). Changing epidemiology of classical and emerging human fungal infections: a review. Jordan J. Biol. Sci. 5, 215-230.

Almeida, J. N. Jr., Motta, A. L., Rossi, F., Abdala, E., Pierrotti, L. C., Kono, A. S. G., et al. (2012). First report of a clinical isolate of Candida haemulonii in Brazil. Clinics 67, 1229-1231. doi: 10.6061/clinics/2012(10)18

Bujdáková, H. (2016). Management of Candida biofilms: state of knowledge and new options for prevention and eradication. Future Microbiol. 11, 235-251. doi: $10.2217 / \mathrm{fmb} .15 .139$

Caggiano, G., Coretti, C., Bartolomeo, N., Lovero, G., De Giglio, O., and Montagna, M. T. (2015). Candida bloodstream infection in Italy: changing epidemiology during 16 years of surveillance. Biomed. Res. Int. 2015, 256580. doi: $10.1155 / 2015 / 256580$

Casey, M. T., McCann, M., Devereux, M., Curran, M., Cardin, C., Convery, M., et al. (1994). Synthesis and structure of the $\mathrm{Mn}_{2}$ (II,II) complex salt $\left[\mathrm{Mn}_{2}\right.$ (oda) $\left.(\text { phen })_{4}\left(\mathrm{H}_{2} \mathrm{O}\right)_{2}\right]\left[\mathrm{Mn}_{2}(\text { oda })_{2}(\text { phen })_{4}\right]\left(\mathrm{odaH}_{2}=\right.$ octanedioic acid): a catalyst for $\mathrm{H}_{2} \mathrm{O}_{2}$ disproportionation. J. Chem. Soc. Chem. Commun. 22, 2643-2645. doi: 10.1039/C39940002643

Cendejas-Bueno, E., Kolecka, A., Alastruey-Izquierdo, A., Theelen, B., Groenewald, M., Kostrzewa, M., et al. (2012). Reclassification of the Candida haemulonii complex as Candida haemulonii (C. haemulonii group I), C. duobushaemulonii sp. nov. (C. haemulonii group II), and C. haemulonii var. vulnera var. nov.: three multiresistant human pathogenic yeasts. J. Clin. Microbiol. 50, 3641-3651. doi: 10.1128/JCM.02248-12

CLSI (2008). Clinical and Laboratory Standards Institute. Reference Method for Broth Dilution Antifungal Susceptibility Testing of Yeasts: Approved Standard $-3 r d$ Edn M27-A3. Wayne, PA: CLSI.

Coyle, B., Kavanagh, K., McCann, M., Devereux, M., and Geraghty, M. (2003). Mode of anti-fungal activity of 1,10-phenanthroline and its $\mathrm{Cu}(\mathrm{II}), \mathrm{Mn}(\mathrm{II})$ and $\mathrm{Ag}(\mathrm{I})$ complexes. Biometals 16, 321-329. doi: 10.1023/A:1020695923788

Creaven, B. S., Devereux, M., Karcz, D., Kellett, A., McCann, M., Noble, A., et al. (2009). Copper(II) complexes of coumarin-derived schiff bases and their anti-Candida activity. J. Inorg. Biochem. 103, 1196-1203. doi: 10.1016/j.jinorgbio.2009.05.017

Creaven, B. S., Egan, D. A., Karcz, D., Kavanagh, K., McCann, M., Mahon, M., et al. (2007). Synthesis, characterisation and antimicrobial activity of copper(II) and manganese(II) complexes of coumarin-6,7-dioxyacetic acid (cdoaH2) and 4-methylcoumarin-6,7-dioxyacetic acid (4-MecdoaH2): X-ray crystal structures of $\left[\mathrm{Cu}(\right.$ cdoa $\left.)(\text { phen })_{2}\right] \cdot 8.8 \mathrm{H}_{2} \mathrm{O}$ and $[\mathrm{Cu}(4-$ Mecdoa) $\left.(\text { phen })_{2}\right] \cdot 13 \mathrm{H}_{2} \mathrm{O}$ (phen=1,10-phenanthroline). J. Inorg. Biochem. 101, 1108-1119. doi: 10.1016/j.jinorgbio.2007.04.010

Devereux, M., McCann, M., Cronin, J. F., Ferguson, G., and McKee, V. (1999). Binuclear and polymeric copper(II) dicarboxylate complexes: synthesis and crystal structures of $\left[\mathrm{Cu}_{2}(\mathrm{pda})(\mathrm{phen})_{4}\right]\left(\mathrm{ClO}_{4}\right)_{2} .5 \mathrm{H}_{2} \mathrm{O}$.EtOH, $\left.\left[\mathrm{Cu}_{2} \text { (oda) (phen }\right)_{4}\right]\left(\mathrm{ClO}_{4}\right)_{2} \cdot 2.67 \mathrm{H}_{2} \mathrm{O} . \mathrm{EtOH}$ and $\left\{\mathrm{Cu}_{2}(\mathrm{pda})_{2}\left(\mathrm{NH}_{3}\right)_{4}\left(\mathrm{H}_{2} \mathrm{O}\right)_{2} \cdot 4 \mathrm{H}_{2} \mathrm{O}\right\}_{n}\left(\mathrm{odaH}_{2}=\right.$ octanedioic acid; $\mathrm{pdaH}_{2}=$ pentanedioic acid; phen = 1,10-phenanthroline). Polyhedron 18, 2141-2148. doi: 10.1016/S0277-5387(99)00100-X

Devereux, M., McCann., M., Leon, V., Geraghty, M., and McKee, V., Wikaira, J. (2000). Synthesis and biological activity of manganese (II) complexes of phthalic and isophthalic acid: X-ray crystal structures of $\left[\mathrm{Mn}(\mathrm{ph})(\mathrm{Phen})_{2}\left(\mathrm{H}_{2} \mathrm{O}\right)\right] \cdot 4 \mathrm{H}_{2} \mathrm{O},\left[\mathrm{Mn}(\mathrm{Phen})_{2}\left(\mathrm{H}_{2} \mathrm{O}\right)_{2}\right]_{2}$ (Isoph) $)_{2}$ (Phen) $14 \mathrm{H}_{2} \mathrm{O}$ and $\left\{\left[\mathrm{Mn}(\mathrm{Isoph})(\text { bipy })_{2}\right]_{4} \cdot 2.75 \text { bipy }\right\}_{\mathrm{n}} \quad\left(\mathrm{phH}_{2}=\right.$ phthalic acid; Isoph $=$ isophthalic acid; Phen =1,10-phenanthroline; bipy =2,2-bipyridine). Met. Based Drugs 7, 275-288. doi: 10.1155/MBD.2000.275

Garcia-Vidal, C., Viasus, D., and Carratalá, J. (2013). Pathogenesis of invasive fungal infections. Curr. Opin. Infect. Dis. 26, 270-276. doi: 10.1097/QCO.0b013e32835fb920

Geraghty, M., Cronin, J. F., Devereux, M., and McCann, M. (2000). Synthesis and antimicrobial activity of copper(II) and manganese(II) $\alpha, \omega$-dicarboxylate complexes. Biometals 13, 1-8. doi: 10.1023/A:10092712 21684

Giusiano, G., Mangiaterra, M., Saito, V. G., Rojas, F., Gómez, V., and Díaz, M. C. (2005). Etiology of fungaemia and catheter colonization in Argentinian paediatric patients. Mycoses 49, 49-54. doi: 10.1111/j.1439-0507.2005. 01184.x
Kawai, A., Yamagishi, Y., and Mikamo, H. (2015). In vitro efficacy of liposomal amphotericin B, micafungin and fluconazole against non-albicans species biofilms. J. Infect. Chemother. 21, 647-653. doi: 10.1016/j.jiac.2015.05.007

Kellett, A., Howe, O., O'Connor, M., McCann, M., Creaven, B. S., McClean, S., et al. (2012). Radical induced DNA damage by cytotoxic square-planar copper(II) complexes incorporating $o$-phthalate and 1,10phenanthroline or 2,2'-dipyridyl. Free Radic. Biol. Med. 53, 564-576. doi: 10.1016/j.freeradbiomed.2012.05.034

Kellett, A., O'Connor, M., McCann, M., McNamara, M., Lynch, P., Rosair, G., et al. (2011). Bis-phenanthroline copper(II) phthalate complexes are potent in vitro antitumour agents with 'self-activating' metallo-nuclease and DNA binding properties. Dalton Trans. 40, 1024-1027. doi: 10.1039/c0dt01607a

Khan, Z. U., Al-Sweih, N. A., Ahmad, S., Al-Kazemi, N., Khan, S., Joseph, L., et al. (2007). Outbreak of fungemia among neonates caused by Candida haemulonii resistant to amphotericin B, itraconazole and fluconazole. J. Clin. Microbiol. 45, 2025-2027. doi: 10.1128/JCM.00222-07

Kharissova, O. V., Mendez-Rojas, M. A., Kharisov, B. I., Méndez, U. O., and Martínez, P. E. (2014). Metal complexes containing natural and artificial radioactive elements and their applications. Molecules 19, 10755-10802. doi: $10.3390 /$ molecules 190810755

Kim, M. N., Shin, J. H., Sung, H., Lee, K., Kim, E. C., Ryoo, N., et al. (2009). Candida haemulonii and closely related species at 5 university hospitals in Korea: identification, antifungal susceptibility, and clinical features. Clin. Infect. Dis. 48, 57-61. doi: 10.1086/597108

Lemire, J. A., Harrison, J. J., and Turner, R. J. (2013). Antimicrobial activity of metals: mechanisms, molecular targets and applications. Nat. Rev. Microbiol. 11, 371-384. doi: 10.1038/nrmicro3028

Leon, V. (2000). Synthesis, Characterization and Catalytic and Biological Activity of New Manganese(II) Carboxylate Complexes [dissertation]. Dublin Institute of Technology, Dublin.

McCann, M., Coyle, B., McKay, S., McCormack, P., Kavanagh, K., Devereux, M., et al. (2004). Synthesis and X-ray crystal structure of $\left[\mathrm{Ag}(\text { phendio })_{2}\right] \mathrm{ClO}_{4}$ (phendio $=1,10$-phenanthroline-5,6-dione) and its effects on fungal and mammalian cells. Biometals 17, 635-645. doi: 10.1007/s10534-004-1229-5

McCann, M., Geraghty, M., Devereux, M., O'Shea, D., Mason, J., and O'Sullivan, L. (2000). Insights into the mode of action of the anti-Candida activity of 1,10-phenanthroline and its metal chelates. Met. Based Drugs 7, 185-193. doi: 10.1155/MBD.2000.185

McCann, M., Kellett, A., Kavanagh, K., Devereux, M., and Santos, A. L. S. (2012). Deciphering the antimicrobial activity of phenanthroline chelators. Curr. Med. Chem. 19, 2703-2714. doi: 10.2174/092986712800609733

McCann, S., McCann, M., Casey, M. T., Devereux, M., McKee, V., McMichael, P., et al. (1997). Manganese(II) complexes of 3,6,9-trioxaundecanedioic acid (3,6,9-tddaH $\left.\mathrm{H}_{2}\right)$ : X-ray crystal structures of $\left[\mathrm{Mn}\left(3,6,9\right.\right.$-tdda) $\left.\left(\mathrm{H}_{2} \mathrm{O}\right)_{2}\right] \cdot 2 \mathrm{H}_{2} \mathrm{O}$ and $\{[\mathrm{Mn}(3,6,9-\mathrm{tdda})(\mathrm{phen}) 2] .3 \mathrm{H} 2 \mathrm{O} . \mathrm{EtOH}\}$ n. Polyhedron 16, 4247-4252. doi: 10.1016/S0277-5387(97)00233-7

Mello, T. P., Ramos, L. S., Braga-Silva, L. A., Branquinha, M. H., and Santos, A. L. S. (2017). Fungal biofilm - a real obstacle against an efficient therapy: lessons from Candida. Curr. Top. Med. Chem. 17, 1987-2004. doi: $10.2174 / 1568026617666170105145227$

Metcalfe, C., and Thomas, A. (2003). Kinetically inert transition metal complexes that reversibly bind to DNA. Chem. Soc. Rev. 32, 215-224. doi: $10.1039 / \mathrm{b} 201945 \mathrm{k}$

Mosmann, T. (1983). Rapid colorimetric assay for cellular growth and survival: application to proliferation and cytotoxicity assays. J. Immunol. Methods 65, $55-63$.

Muro, M. D., Motta, F. A., Burger, M., Melo, A. S. A., and Dalla-Costa, L. M. (2012). Echinocandin resistance in two Candida haemulonii isolates from pediatric patients. J. Clin. Microbiol. 50, 3783-3785. doi: 10.1128/JCM.01136-12

Nett, J. E. (2014). Future directions for anti-biofilm therapeutics targeting Candida. Expert. Revi. Anti. Infect. Ther. 12, 375-382. doi: $10.1586 / 14787210.2014 .885838$

Peeters, E., Nelis, H. J., and Coenye, T. (2008). Comparison of multiple methods for quantification of microbial biofilms grown in microtiter plates. J. Microbiol. Methods 72, 157-165. doi: 10.1016/j.mimet.2007.11.010

Rajendran, R., Sherry, L., Nile, C. J., Sherriff, A., Johnson, E. M., Hanson, M. F., et al. (2016). Biofilm formation is a risk factor for mortality in patients with 
Candida albicans bloodstream infections-Scotland, 2012-2013. Clin. Microbiol. Infect. 22, 87-93. doi: 10.1016/j.cmi.2015.09.018

Ramage, G., Robertson, S. N., and Williams, C. (2014). Strength in numbers: antifungal strategies against fungal biofilms. Int. J. Antimicrob. Agents 43, 114-120. doi: 10.1016/j.ijantimicag.2013.10.023

Ramage, G., Walle, K. V., Wickes, B. L., and López-Ribot, J. L. (2001). Standardized method for in vitro antifungal susceptibility testing of Candida albicans biofilms. Antimicrob. Agents Chemother. 45, 2475-2479. doi: 10.1128/AAC.45.9.2475-2479.2001

Ramos, L. S., Figueireido-Carvalho, M. H., Barbedo, L. S., Ziccardi, M., Chaves, A. L., Zancopé-Oliveira, R. M., et al. (2015). Candida haemulonii complex: species identification and antifungal susceptibility profiles of clinical isolates from Brazil. J. Antimicrob. Chemother. 70, 111-115. doi: 10.1093/jac/ dku321

Ramos, L. S., Oliveira, S. C. S., Branquinha, M. H., and Santos, A. L. S. (2017). Planktonic growth and biofilm formation profiles in Candida haemulonii species complex. Med. Mycol. doi: 10.1093/mmy/myx005

Richardson, M., and Lass-Flörl, C. (2008). Changing epidemiology of systemic fungal infections. Clin. Microbiol. Infec. 4, 5-24. doi: 10.1111/j.1469-0691.2008.01978.x

Ruan, S. Y., Kuo, Y. W., Huang, C. T., Hsiue, H. C., and Hsueh, P. R. (2010). Infections due to Candida haemulonii: species identification, antifungal susceptibility and outcomes. Int. J. Antimicrob. Agents 35, 85-88. doi: 10.1016/j.ijantimicag.2009. 08.009
Sanguinetti, M., Posteraro, B., and Lass-Flörl, C. (2015). Antifungal drug resistance among Candida species: mechanisms and clinical impact. Mycoses 58, 2-13. doi: 10.1111/myc.12330

Thornton, L., Dixit, V., Assad, L. O., Ribeiro, T. P., Queiroz, D. D., Kellett, A., et al. (2016). Water-soluble and photo-stable silver(I) dicarboxylate complexes containing 1,10-phenanthroline ligands: antimicrobial and anticancer chemotherapeutic potential, DNA interactions and antioxidant activity. $J$. Inorg. Biochem. 159, 120-132. doi: 10.1016/j.jinorgbio.2016.02.024

Ziccardi, M., Souza, L. O. P., Gandra, R. M., Galdino, A. C., Baptista, A. R., Nunes, A. P., et al. (2015). Candida parapsilosis (sensu lato) isolated from hospitals located in the Southeast of Brazil: species distribution, antifungal susceptibility and virulence attributes. Int. J. Med. Microbiol. 305, 848-859. doi: $10.1016 /$ j.ijmm.2015.08.003

Conflict of Interest Statement: The authors declare that the research was conducted in the absence of any commercial or financial relationships that could be construed as a potential conflict of interest.

Copyright $\odot 2017$ Gandra, Mc Carron, Fernandes, Ramos, Mello, Aor, Branquinha, McCann, Devereux and Santos. This is an open-access article distributed under the terms of the Creative Commons Attribution License (CC BY). The use, distribution or reproduction in other forums is permitted, provided the original author(s) or licensor are credited and that the original publication in this journal is cited, in accordance with accepted academic practice. No use, distribution or reproduction is permitted which does not comply with these terms. 